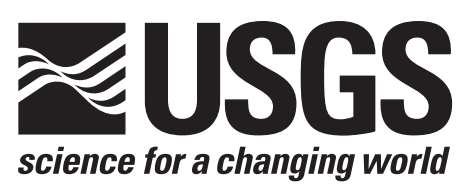

\title{
Change in the Length of the Middle Section of the Chandeleur Islands Oil Berm, November 17, 2010, through September 6, 2011
}

By N.G. Plant and K.K. Guy

Open-File Report 2013-1075

U.S. Department of the Interior

U.S. Geological Survey 


\section{U.S. Department of the Interior \\ Ken Salazar, Secretary}

\section{U.S. Geological Survey \\ Suzette M. Kimball, Acting Director}

U.S. Geological Survey, Reston, Virginia 2013

For product and ordering information:

World Wide Web: http://www.usgs.gov/pubprod

Telephone: 1-888-ASK-USGS

For more information on the USGS - the Federal source for science about the Earth, its natural and living resources, natural hazards, and the environment:

World Wide Web: http://www.usgs.gov

Telephone: 1-888-ASK-USGS

Suggested citation:

Plant, N.G., and Guy, K.K., 2013, Change in the length of the middle section of the Chandeleur Islands oil berm, November 17, 2010, through September 6, 2011: U.S. Geological Survey Open-File Report 2013-1075, 8 p.

Any use of trade, product, or firm names is for descriptive purposes only and does not imply endorsement by the U.S. Government.

Although this report is in the public domain, permission must be secured from the individual copyright owners to reproduce any copyrighted material contained within this report. 


\section{Contents}

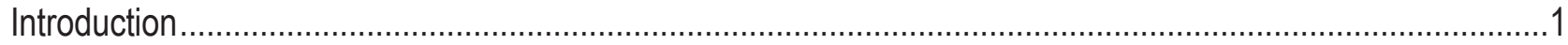

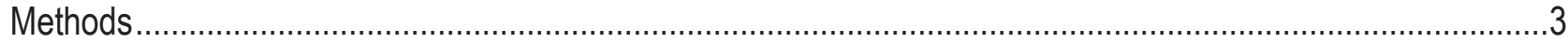

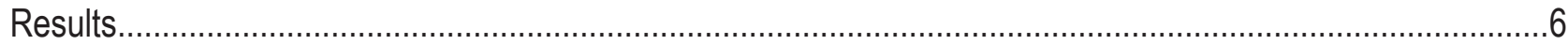

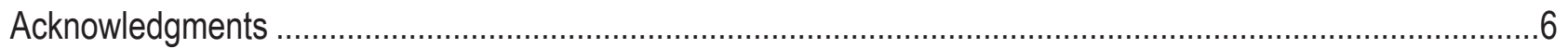

\section{Figures}

1. Chandeleur and Breton Islands (part of the Breton Island National Wildlife Refuge), the Mississippi River Delta, the site of the Deepwater Horizon oil spill, and the location of the full extent of the Chandeleur

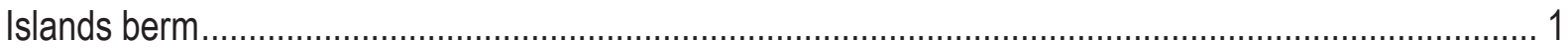

2. The Chandeleur Islands berm divided into northern, middle, and southern sections............................ 2

3. The completed middle section of the Chandeleur Islands berm ....................................................... 3

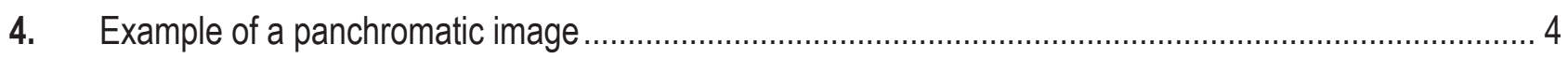

5. Example of isolines generated on the basis of pixel value .............................................................. 4

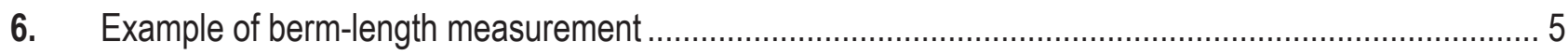

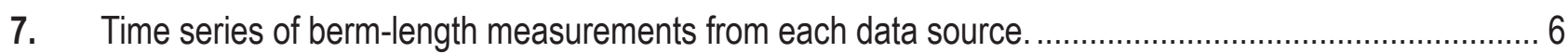

\section{Tables}

1. Satellite multispectral and panchromatic image resolutions............................................................ 4

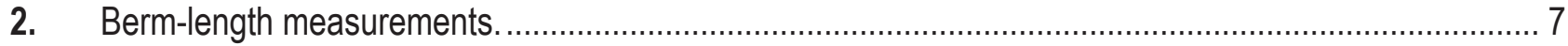




\section{Change in the Length of the Middle Section of the Chandeleur Islands Oil Berm, November 17, 2010, through September 6, 2011}

By N.G. Plant and K.K. Guy

\section{Introduction}

On April 20, 2010, an explosion on the Deepwater Horizon oil rig drilling at the Macondo Prospect site in the Gulf of Mexico resulted in a marine oil spill that continued to flow through July 15, 2010. One of the affected areas was the Breton National Wildlife Refuge, which consists of a chain of low-lying islands, including Breton Island and the Chandeleur Islands, and their surrounding waters. The island chain is located approximately $115-150$ kilometers $(\mathrm{km})$ north-
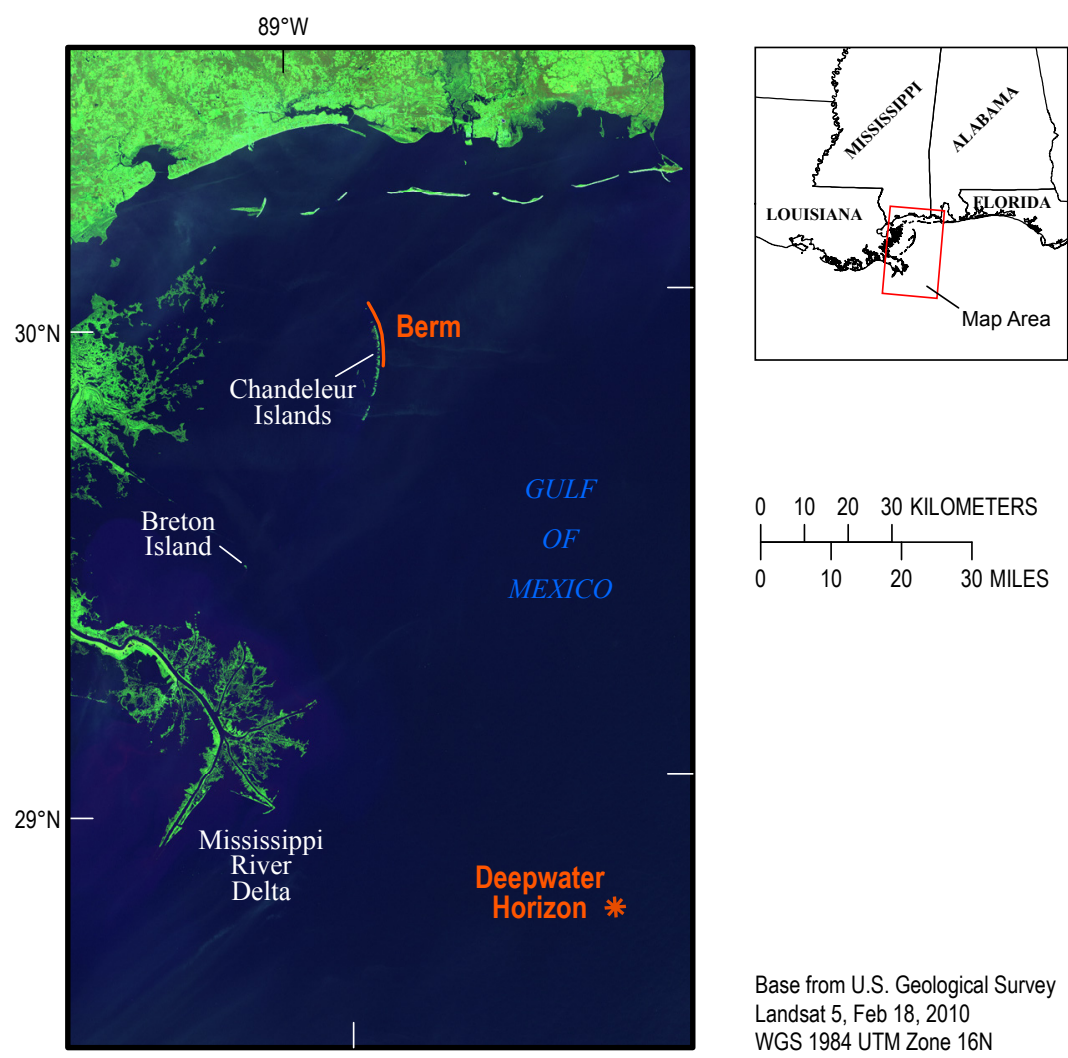

Base from U.S. Geological Survey Landsat 5, Feb 18, 2010

WGS 1984 UTM Zone 16N

Figure 1. Chandeleur and Breton Islands (part of the Breton Island National Wildlife Refuge), the Mississippi River Delta, the site of the Deepwater Horizon oil spill, and the location of the full extent of the Chandeleur Islands berm. The background image is U.S. Geological Survey Landsat 5 taken February 18, 2010, prior to the start of berm construction. 


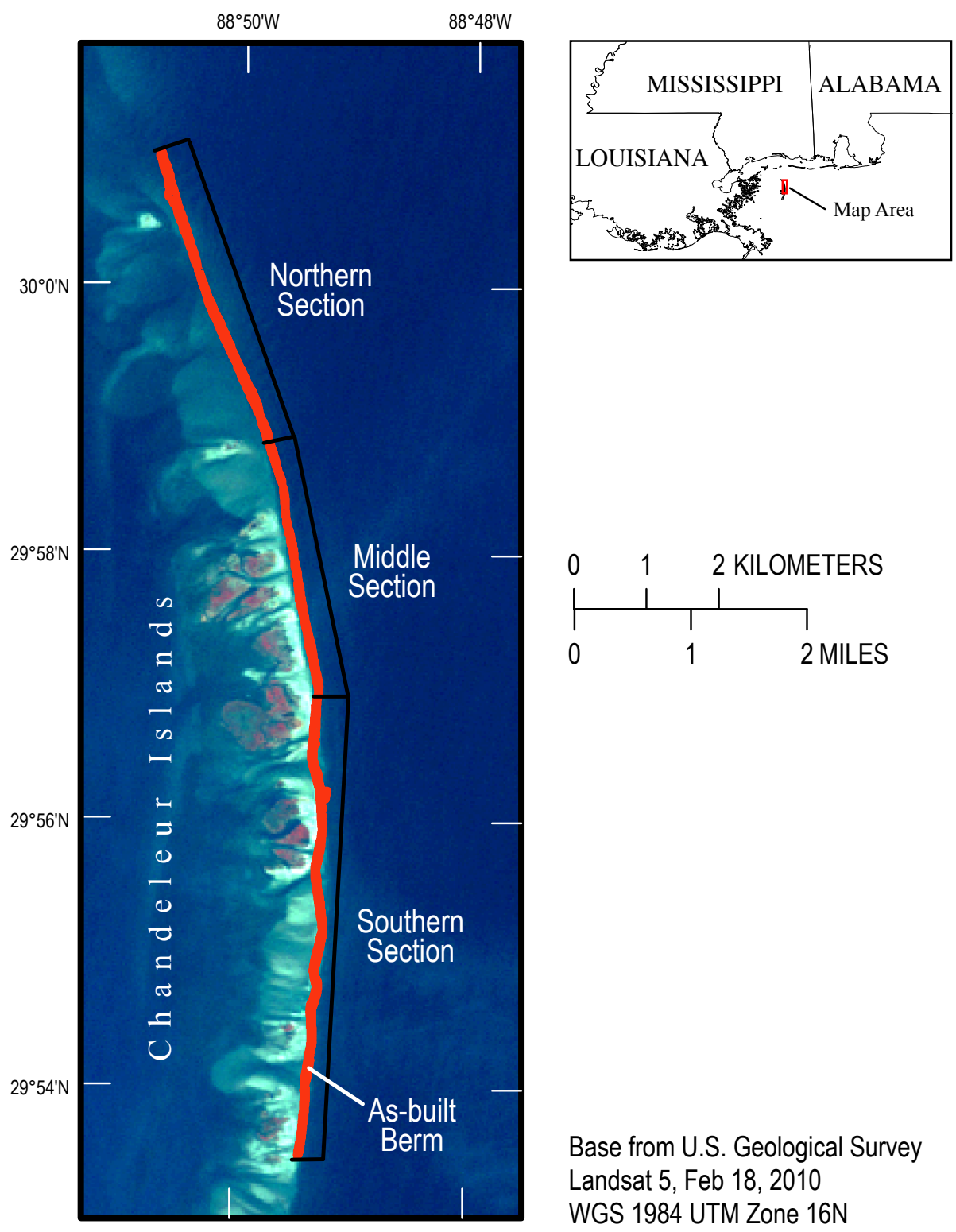

Figure 2. The Chandeleur Islands berm divided into northern, middle, and southern sections. The asbuilt berm footprint is shown in orange. The background image is U.S. Geological Survey Landsat 5 taken February 18, 2010, prior to the start of berm construction.

northwest of the spill site (fig. 1). A sand berm was constructed seaward of, and on, the island chain. Construction began at the northern end of the Chandeleur Islands in June 2010 and ended in April 2011. The berm consisted of three distinct sections based on where the berm was placed relative to the islands (fig. 2). The northern section of the berm was built in open water on a submerged portion of the Chandeleur Islands platform. The middle section was built approximately 70-90 meters (m) seaward of the Chandeleur Islands. The southern section was built on the islands' beaches. Repeated Landsat and SPOT satellite imagery and airborne lidar were used to observe the disintegration of the berm over time. The methods used to analyze the remotely sensed data and the resulting, derived data for the middle section (fig. 3 ) are reported here. 

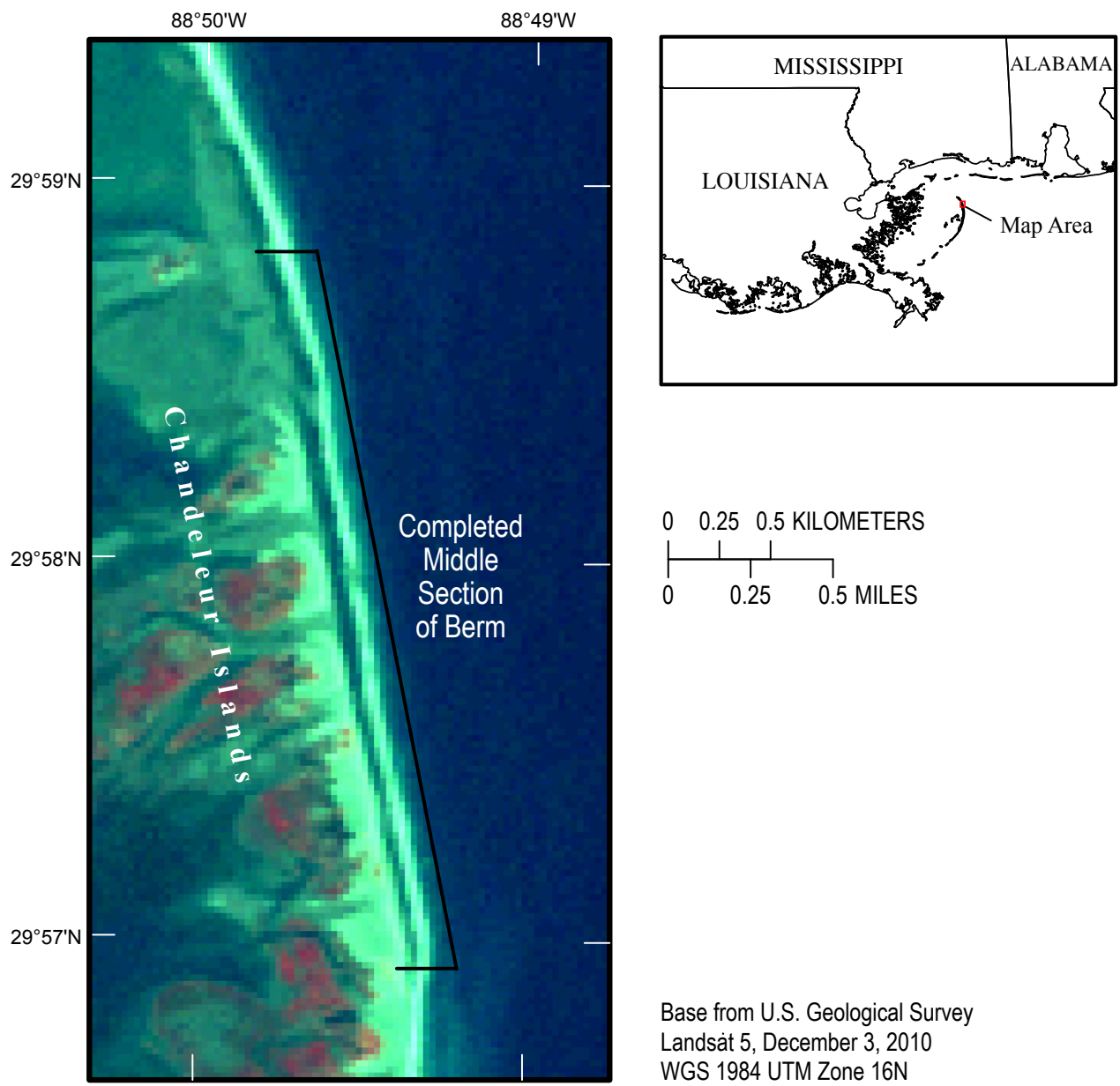

Base from U.S. Geological Survey

Landsät 5, December 3, 2010

WGS 1984 UTM Zone 16N

Figure 3. The completed middle section of the Chandeleur Islands berm. This U.S. Geological Survey Landsat 5 image was taken December 3, 2010, and shows the middle section of the berm, which lies approximately 70-90 $\mathrm{m}$ offshore of the Chandeleur Islands.

\section{Methods}

The Chandeleur Islands berm was built approximately 50-m wide (above mean high water) and 2-m high relative to the North American Vertical Datum of 1988 (NAVD 88) and using the 1996 Geoid model (Geoid 96). Because of the large size of the berm combined with the highly reflective nature of sand, observations from satellite imagery were possible. Medium resolution $(5-30 \mathrm{~m})$ Landsat and SPOT satellite imagery (table 1) provided relatively frequent observation opportunities. Additionally, two high resolution lidar elevation datasets were used for measuring berm length. A total of 29 observations were made from November 17, 2010, the first date usable satellite imagery was available after the completion of the middle section of the berm, to September 6, 2011, when the berm no longer occupied its as-built footprint. For the purpose of these berm-length measurements, only those portions of the berm that occupied its as-built footprint (as estimated from a sequence of SPOT satellite images obtained during the construction period: September 5, 2010; October 1, 2010; December 7, 2010; and April 3, 2011) were measured. 
Table 1. Satellite multispectral and panchromatic image resolutions.

\begin{tabular}{|c|c|c|}
\hline Satellite & Multispectral resolution & Panchromatic resolution \\
\hline SPOT 4 & $20 \mathrm{~m}$ & $10 \mathrm{~m}$ \\
\hline SPOT 5 & $10 \mathrm{~m}$ & $5 \mathrm{~m}$ \\
\hline Landsat 5 & $30 \mathrm{~m}$ & (none) \\
\hline Landsat 7 & $30 \mathrm{~m}$ & $15 \mathrm{~m}$ \\
\hline
\end{tabular}

Satellite images were selected on the basis of availability, clear view of the berm, and resolution (ground sampling interval or cell size). The sensors on Landsat 5, Landsat 7, SPOT 4, and SPOT 5 differ in their spectral bands and resolution (table 1). When available, panchromatic bands were used because of their higher resolutions. When not available, single bands from the multispectral images were selected. Band 5 (1.55 to 1.75 micrometers $(\mu \mathrm{m}))$ at 30-m resolution was used for

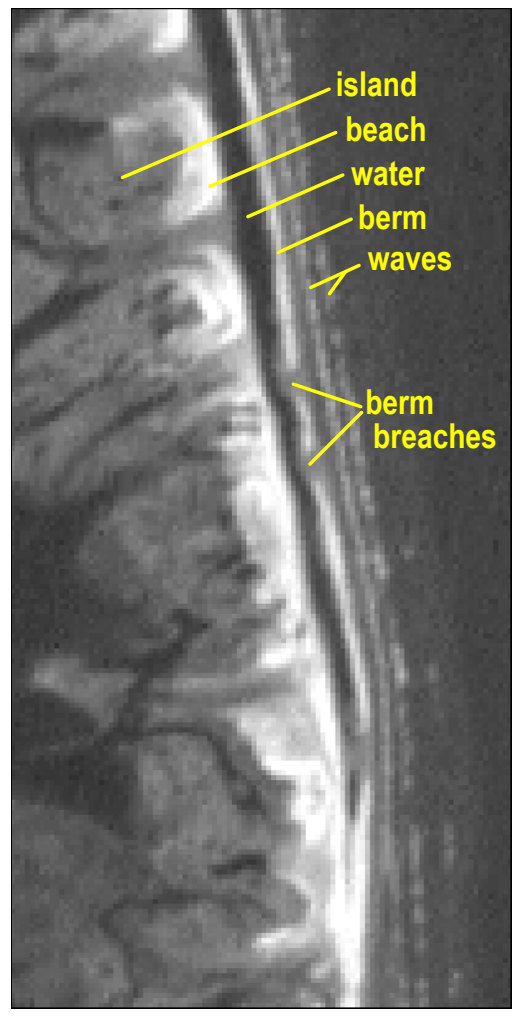

Figure 4. Example of a panchromatic image. Water, waves, island, beach, berm, and breaches in the berm are labeled. The dry sand berm and beaches appear as light grays to white, the water as darker shades of gray, and the wet sand of the berm breaches as mid-tone grays.

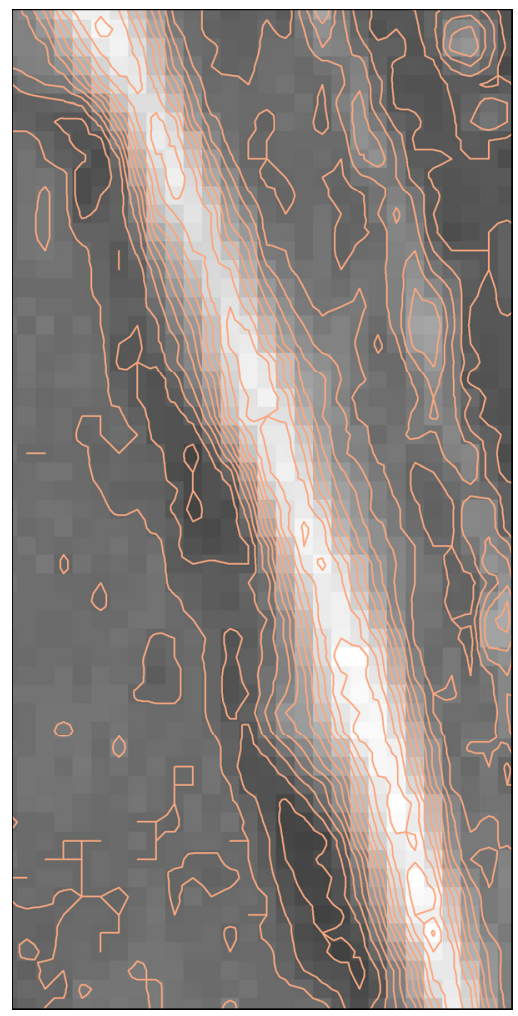

Figure 5. Example of isolines generated on the basis of pixel value. The isolines are drawn in pink on top of the U.S. Geological Survey Landsat 7 panchromatic image from which they were made. The berm is the wide, light streak of pixels running from the upper left to the lower right of the figure. The mid-tone grays in the upper right are waves. 


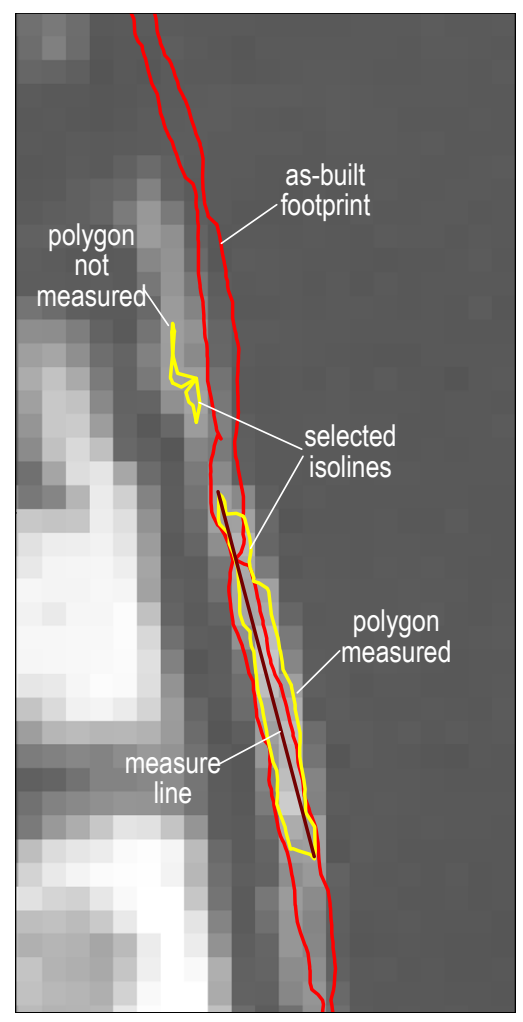

Figure 6. Example of berm-length measurement. The red line represents the berm's as-built footprint. One yellow line encloses a small area that appears to be on the berm; however, this area does not fall within the as-built footprint. Therefore, this area is no longer considered part of the berm and is not measured. A second yellow line encloses a larger area and mostly falls within the as-built footprint. The brown line represents the resulting berm-length measurement.

Landsat 5 images. Of the four 20-m resolution multispectral SPOT 4 images used, band 1 ( 0.50 to $0.59 \mu \mathrm{m}$ ) was used for three dates and band $3(0.78$ to $0.89 \mu \mathrm{m})$ was used for one date (table 2$)$.

Water has lower reflectivity than sand in the satellite images and, therefore, has a lower pixel intensity value. In a typical gray-scale representation where low values are dark and high values are light, water will appear dark and sand will appear very light or white. Wet sand is less reflective than dry sand and appears in mid-tone grays (fig. 4). The relatively high pixel values of dry sand were used to delimit the berm footprint. This method is subject to bias errors caused by differences in water levels when different images were acquired, and no corrections for these biases have been made here. The water levels from a nearby location (Station 8761305, Shell Beach, Louisiana), referenced to the mean sea level datum, are included in this report (table 2).

Each image was visually examined to determine the footprint of the berm. Isolines based on pixel values were generated for each image using the Contour tool in ArcGIS ${ }^{\circledR}$ (fig. 5). A contour interval of 5 intensity units was used for Landsat 5 band 5, SPOT 4, and SPOT 5 images (fig. 5), and a contour interval of 2 intensity units was used for Landsat 7 panchromatic images. Because the pixel-intensity values for water, dry sand, and wet sand were not consistent between images, fixed contour levels were not used to delineate the berm. Instead, the contours were overlaid on the image and one of these contours was selected to represent the footprint of each berm segment as a polygon in the geographic information system (GIS). This footprint was then used to measure the length of the berm segment. Only those portions of the berm footprint that occupied the original as-built footprint were used to measure berm length (fig. 6). Once sand was moved beyond the as-built footprint by overwash, inundation, or breaching, it no longer contributed to the measured length of the berm.

The berm footprints obtained from two lidar elevation datasets were based on elevation rather than reflectivity. Contours were generated at 10-centimeter $(\mathrm{cm})$ intervals and were compared to the berm footprints obtained from satellite imagery. The 100-cm (NAVD 88, Geoid 96) contour was selected to represent the subaerial portion of the berm. This level is well above the typical 
water level, allowing retrieval of topographic lidar from each survey. Similarly to the treatment of the satellite imagery, berm-length measurements were estimated where the 100-cm lidar-elevation contour fell within the as-built footprint. Some clusters of small polygons appeared in the lidar berm footprints. These clusters were measured as if they were one large polygon.

\section{Results}

The results from the satellite and lidar data analysis are presented in figure 7, which shows a time series of berm lengths derived from each of the sensors. The measurements are listed in table 2. The accuracy of the berm-length measurements was quantified from the differences between sequential length measurements, excluding the large length changes observed on January 12, 2011, via Landsat 7. The root mean square difference was $236 \mathrm{~m}$.

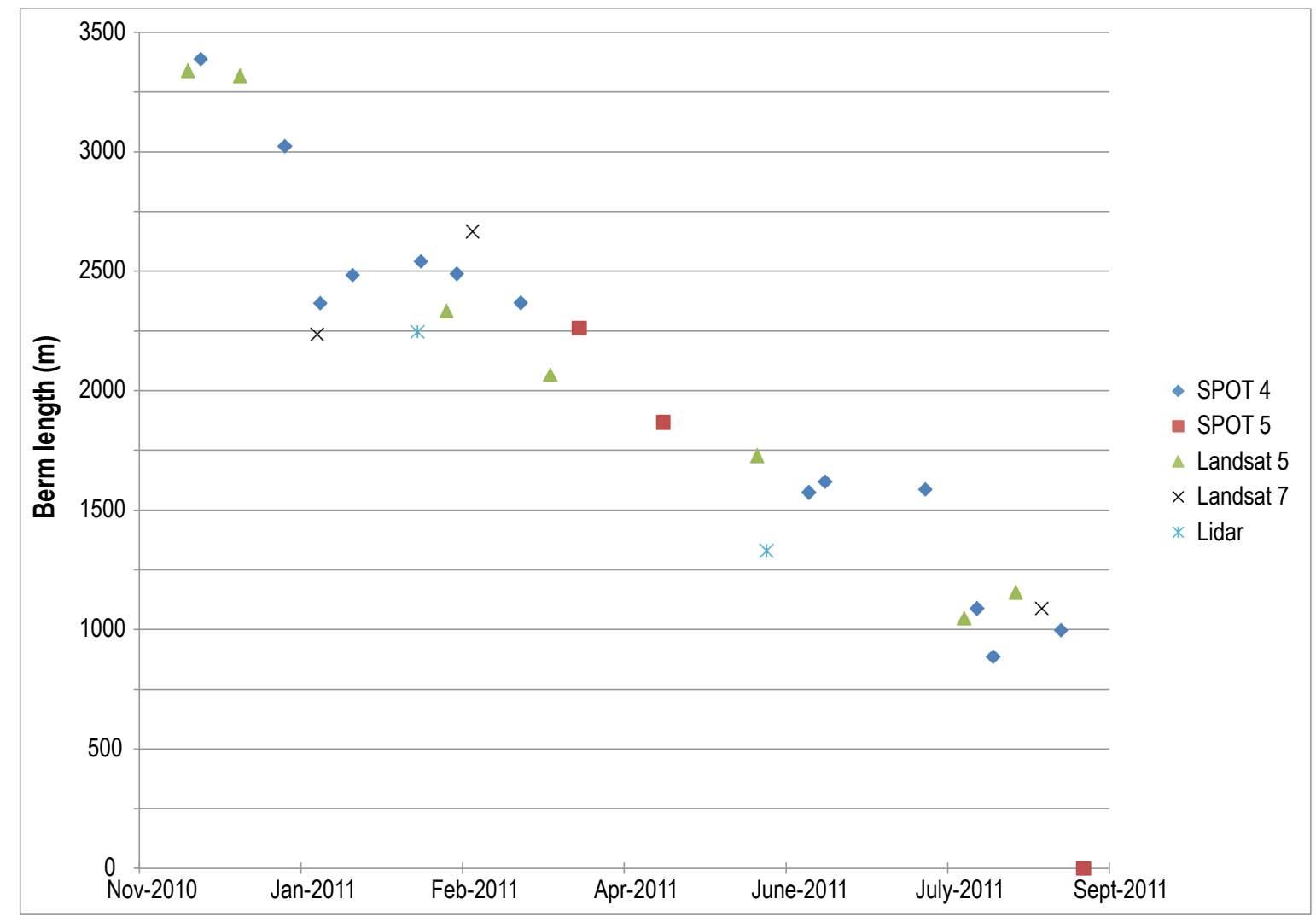

Figure 7. Time series of berm-length measurements from each data source.

\section{Acknowledgments}

The data collection and analysis presented in this report were conducted with support from the U.S. Geological Survey's Coastal and Marine Geology Program. The clarity of the report was improved by reviews from C. Sherwood and J. Flocks. We thank B. Boynton, T. Burress, and K. Naugle for editing, producing, and publishing the final document. 


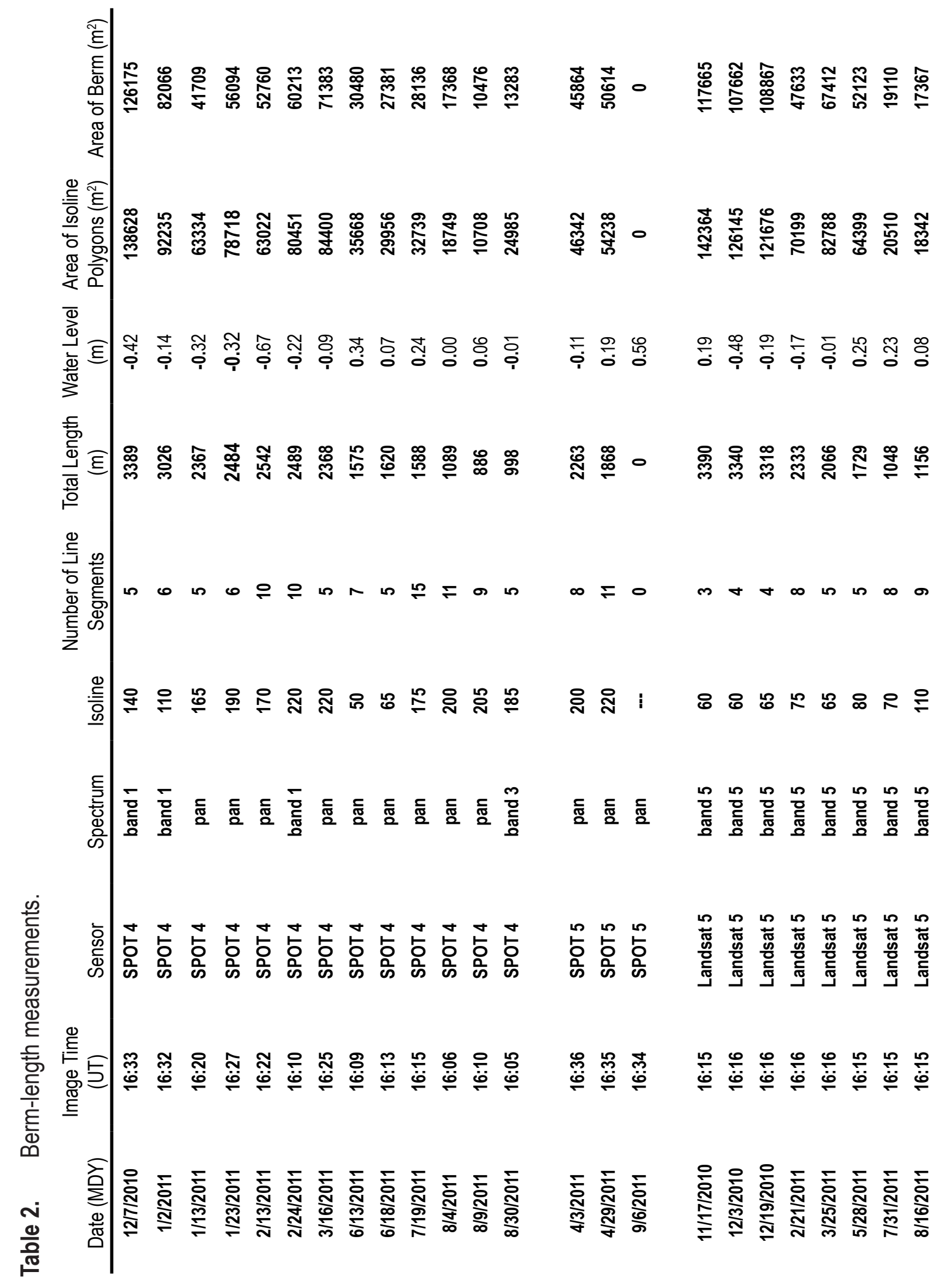




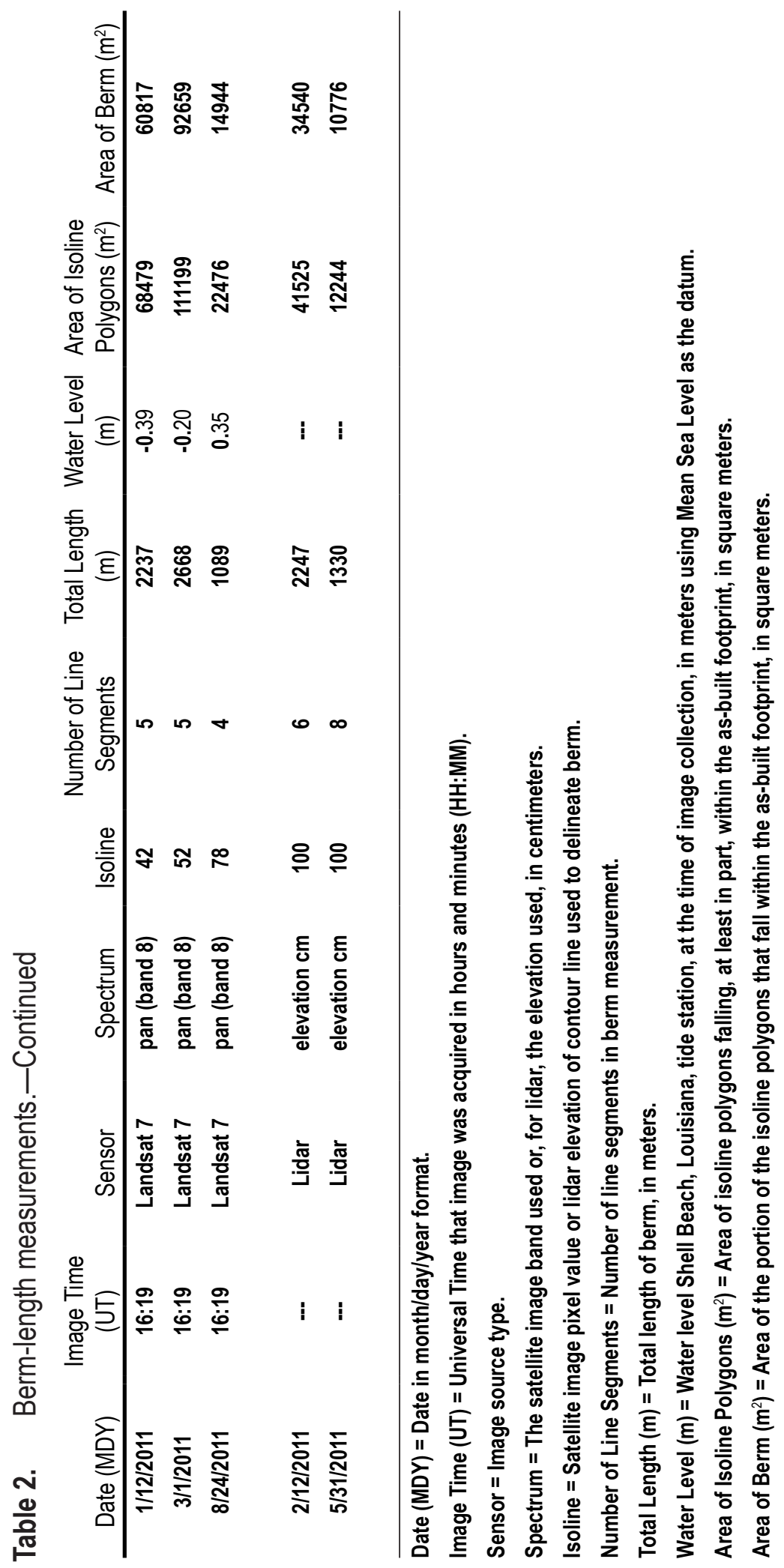

